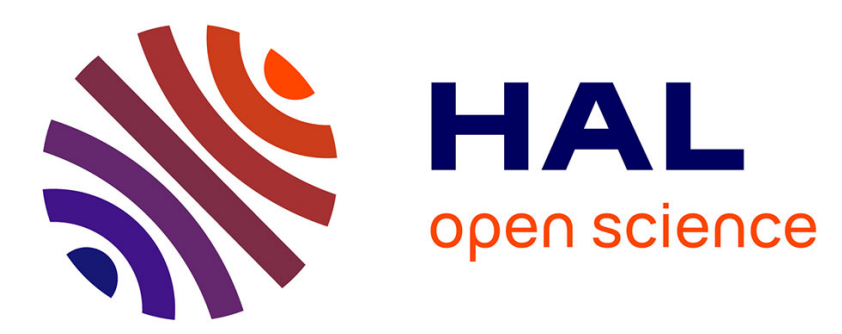

\title{
Paleostress analysis of the volcanic margins of Yemen
}

Khaled Khanbari, Philippe Huchon

\section{To cite this version:}

Khaled Khanbari, Philippe Huchon. Paleostress analysis of the volcanic margins of Yemen. Arabian Journal of Geosciences, 2010, 3, pp.529-538. 10.1007/s12517-010-0164-8 . hal-00574208

\section{HAL Id: hal-00574208 \\ https://hal.science/hal-00574208}

Submitted on 7 Apr 2011

HAL is a multi-disciplinary open access archive for the deposit and dissemination of scientific research documents, whether they are published or not. The documents may come from teaching and research institutions in France or abroad, or from public or private research centers.
L'archive ouverte pluridisciplinaire $\mathbf{H A L}$, est destinée au dépôt et à la diffusion de documents scientifiques de niveau recherche, publiés ou non, émanant des établissements d'enseignement et de recherche français ou étrangers, des laboratoires publics ou privés. 
Arab. J. Geosciences, Accepted 26-05-2010

\title{
Paleostress analysis of the volcanic margins of Yemen
}

\author{
Khaled Khanbari $^{\mathrm{a}, \mathrm{b}}$, Philippe Huchon ${ }^{\mathrm{c}, \mathrm{d}}$ \\ ${ }^{a}$ Department of Earth and Environmental Sciences, Sana'a University, \\ PO Box 12167, Sana'a, Yemen \\ Email:kkhanbari@hotmail.com \\ ${ }^{\mathrm{b}}$ Yemen Remote Sensing and GIS Center, Yemen \\ ${ }^{c}$ iSTeP, UMR 7193, UPMC Université Paris 6 \\ Case 129, 4 place Jussieu 75005 Paris, France \\ diSTeP, UMR 7193, CNRS, Paris, France
}

\begin{abstract}
The western part of Yemen is largely covered by Tertiary volcanics and is bounded by volcanic margins to the west (Red Sea) and the south (Gulf of Aden). The oligo-miocene evolution of Yemen results from the interaction between the emplacement of the Afar plume, the opening of the Red Sea and the westward propagation of the Gulf of Aden. Structural and microtectonic analyses of fault slip data collected in the field reveal that the volcanic margins of Yemen are affected by three main extensional tectonic events. The chronological order of these events is as follows: first E-W extension was associated with the emplacement of volcanic traps of Yemen, then NE-SW extension was related to the Red Sea rifting and finally the volcanic margin was submitted to $\mathrm{N} 160^{\circ} \mathrm{E}$ extension, perpendicular to the overall trend of the Gulf of Aden, that we interpret as induced by the westward propagation of the oceanic ridge of the Gulf of Aden.
\end{abstract}

\section{تحليل الاجهادات القديمة لحواف اليمن البركانية}

$$
\text { ملثص: }
$$




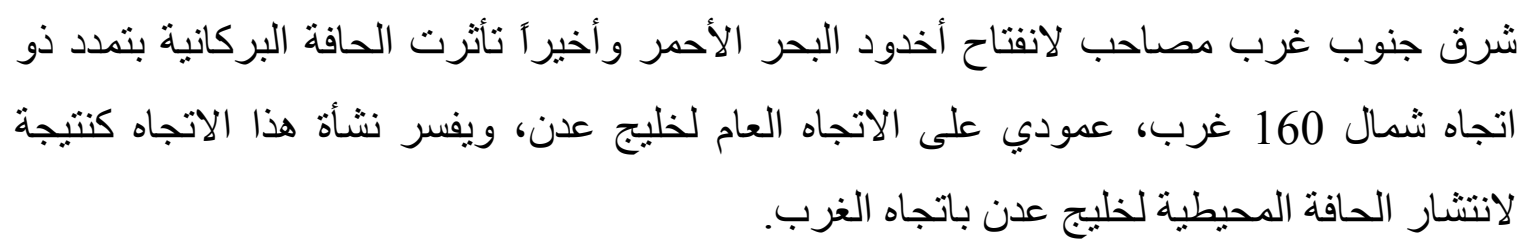

Keywords Continental extension; Volcanic margin; Red Sea; Gulf of Aden; Afar plume

\section{Introduction}

The movement of the Arabian plate away from Africa in a north-east direction since 30 Ma (Beydoun 1970; Le Pichon and Francheteau 1978) led to opening of two young oceanic basins: the Red Sea, between Africa (Nubia) and Arabia, and the Gulf of Aden between Somalia and Arabia (see a review in Bosworth et al. 2005) (Fig. 1). These two oceanic basins are connected in a complicated pattern within the area of the Afar triple junction. The Sheba ridge of the Gulf of Aden initiated from the Carlsberg ridge in the Indian Ocean and progressed westwards into Afar region (Laughton et al. 1970; Manighetti et al. 1997; Fournier et al. 2010). Its general trend is WSW-ENE (N70 ${ }^{\circ}$ ). The Gulf of Aden is thus oblique to the motion of Arabia toward the north-east (Dauteuil et al. 2001). The oldest magnetic lineations are identified in the eastern part of the Gulf of Aden and correspond to chron 5D (17.8 Ma) (Sahota 1990; Leroy et al. 2004; d'Acremont et al. 2010) and chron 6 (20 Ma) (Fournier et al. 2010). The oceanic floor becomes younger in the westernmost part of the Gulf of Aden, where the oldest magnetic anomaly corresponds to chron 2 or possibly 2A (3 Ma) (Cochran 1981; Audin 1999). The oceanization would then have started around $20 \mathrm{Ma}$, and then the ridge propagated toward the west into Afar (Courtillot et al. 1980; Manighetti et al. 1997).

The Red Sea is a narrow oceanic rift oriented NW-SE which extends from the Sinai Peninsula in the north to the strait of Bab-El Mandeb in the south. Only its central part is characterized by organized magnetic lineations (Cochran 1983). The southern and northern parts show no sign of seafloor spreading (Ehrhardt et al. 2005). However, Le Pichon and Gaulier (1988) proposed that the Red Sea spreading started at about $13 \mathrm{Ma}$ although magnetic anomalies indicate a younger age at $5 \mathrm{Ma}$ (Izzeldin 1987). The age of 
the onset of rifting is still disputed (Hughes et al. 1991) but is generally considered to be late Oligocene (Bosworth et al. 2005).

Yemen is located on the southwestern corner of the Arabian plate on the eastern margin of the Red Sea and on the northern margin of the Gulf of Aden, opposite to Afar depression (Fig. 1). The western part of Yemen represents a typical volcanic margin resulting from the magmatic activity of the Afar plume since $30 \mathrm{Ma}$ (Baker et al. 1996; Hoffmann et al. 1997). The Tertiary basin in the western part of Yemen (Tihama coastal plain) is also related to rifting of the Red Sea (Beydoun et al. 1996).

The aim of this paper is to study the extensional deformations of the volcanic margins of Yemen and to discuss the relationship between extension, magmatism and kinematics associated to the rifting and subsequent spreading of the Red Sea and the Gulf of Aden. We first briefly describe the geology of Yemen, then summarize previous work on the link between extension and magmatism in Yemen before presenting new structural data in three selected areas of western Yemen.

\section{Geological setting of Yemen}

Geology of Yemen extends from the Archean to the Cenozoic (Geukens 1960; Beydoun 1964; Greenwood and Blackley 1967) (Fig. 2). The Proterozoic basement, largely metamorphic (Whitehouse et al. 2001) is unconformably overlain by Ordovician ferrigeneous sandstones, Permian black shales and early Jurassic marls and sandstones (Kohlan Formation) (Ziegler 2001). The late Jurassic is characterized by well-developed transgressive series composed of marls and limestones (Amran Group). These platform series are overlain by Cretaceous continental sandstones (Tawilah Group). Then, during the Cenozoic, the geological evolution of Yemen is dominated by (1) the impingement of the Afar plume beneath the Afro-Arabian lithosphere and (2) the development of the Red Sea and Gulf of Aden rifts and their subsequent oceanization.

The western part of Yemen is characterized by the Tertiary volcanics (Traps of Yemen) related to the Afar plume (Civetta et al. 1978; Capaldi et al. 1987; Chiesa et al. 1983, 1989), whereas the eastern part of Yemen is characterized by Paleocene-Eocene sedimentation of limestone, marl and gypsum (Hadramout Group) and Oligocene- 
Miocene (syn-rift) sedimentation of conglomerates, sandstones, marls, gypsum, limestones and shales (Shihr Group) (Beydoun 1964; Haitham and Nani 1990; Bott et al. 1992). Therefore the western part of Yemen represents a volcanic margin along the Red Sea coast and the western part of the coast of the Gulf of Aden, while the eastern part is a non-volcanic margin. Tard et al. (1991) shows that the southern part of the volcanic margin (Aden margin) presents offshore the characteristics features of a volcanic passive margin, in particular seaward dipping reflectors.

The Yemen Volcanics cover an area of approximately $45000 \mathrm{~km} 2$. Their thickness is more than 2500 meters in the western part but they thin eastward and are only a few tens of meters thick near the contact with the pre-Mesozoic basement (Fig. 2). These Tertiary volcanics consist of both lava flows and intrusions. The lava flows are typical bimodal series, which include alkaline and transitional rocks (Civetta et al. 1978; Capaldi et al. 1987; Chiesa et al. 1989; Huchon et al. 1991) while the intrusions consist of granites that occur mainly along the western border of the plateau (Capaldi et al. 1987; Geoffroy et al. 1998). The granitic bodies are generally alkaline or peralkaline granites and are produced by fractional crystallization from basic magmas (Capaldi et al. 1987; Chazot and Bertrand 1995). All lava series were fed by dykes emplaced throughout the magmatic activity.

The Tertiary volcanics and intrusives of Yemen are related to the Afar mantle plume that impacted the Arabia-Africa area during the Oligocene. They may be also partly related to the opening of the Red Sea and the Gulf of Aden. The lava flows were erupted into two stages (Chiesa et al. 1983): early basaltic traps ( $>2 \mathrm{~km}$ thick) were produced between 31-29 Ma and 26 Ma (Civetta et al. 1978; Chiesa et al. 1989; Baker et al. 1996) while the second stage is comprised of acidic rocks dated between 23-18 Ma (Civetta et al. 1978; Mohr 1991; Zumbo et al. 1995). Riisager et al. (2005) has further refined these ages on the basis of Ar-Ar geochronology and magnetostratigraphy, evidencing a first and short phase of basaltic volcanism between $30.3 \mathrm{Ma}$ and 26.6 Ma followed by acidic and bimodal volcanics until 27.7 Ma. Late Miocene to Quaternary volcanics also occurs in different parts of Yemen (Huchon et al. 1991). The Quaternary volcanics are characterized by a basaltic activity with formation of volcanic cones (Chazot et al. 1998). 
The geological map of Yemen (Fig. 2) shows striking structural directions in the basement, especially NE-SW directions. During the Mesozoic, several rift basins formed (Fig. 2): the NW-trending Marib-Shabwa basins (Brannan et al., 1997) and the WNWtrending Sayun-Al Masila and Jiza-Qamar basins further east (Redfern and Jones, 1995; Beydoun et al., 1996; Bosence, 1997). These basins have been affected by three successive phases of rifting: during the Late Jurassic, associated with the fragmentation of Gondwana, then during Early to mid-Cretaceous, corresponding to the separation of India from Madagascar and finally during Cenozoic (Ellis et al., 1996; Brannan et al., 1999; Schüppel and Wienholz 1990; Watchorn et al. 1998; Ziegler, 2001). Cenozoic NW-trending normal faulting affects both the sedimentary cover and the Tertiary volcanics. This trend is parallel to the Red Sea rift. The eastern part of Yemen is affected by ENE-WSW to WNW-ESE trending faults which do not, in general, parallel the trend of the Gulf of Aden but rather display a pattern typical of oblique rifting (Fantozzi et al. 1996; Fournier et al. 2004; Bellhasen et al. 2006).

\section{Extension and magmatism: former studies}

The existence of Afar plume under the southern Red Sea at $30 \mathrm{Ma}$ is responsible for the initiation of a period of a major flood volcanism. Therefore, the Yemen volcanic margin is a key area to understand the geodynamics of the triple junction, the emplacement of the Afar plume and the relationships between extension and magmatism. The Yemen margin has clearly undergone extension since the beginning of rifting of the Red Sea and the Gulf of Aden, but the relationship between volcanism and extension is not simple. Two types of extensional margins are classically distinguished: (1) active rifted margins where uplift and magmatism precedes rifting, and (2) passive rifted margins which start by rifting then uplift and limited magmatism until the oceanic spreading starts. The passive model thus requires that extension predates any uplift and magmatism whereas in the active model uplift predates magmatism and extension.

In terms of relations between plume magmatism and extensional tectonics, most of research work focused on the active rift system of the Afar region (Gaulier and Huchon 1991, Manighetti et al. 1998). In the southern margin of Yemen, Menzies et al. (1992) 
first suggested that magmatism was followed by synchronous crustal extension and uplift. On the southern Red Sea margin in Yemen, Davison et al. (1994) recognized a major episode of flood volcanism between 30 and $20 \mathrm{Ma}$, with extensional faulting beginning after the eruption of volcanic rocks. They also recognized that the regional direction of extension was mainly NE-SW and they suggest that there is no direct spatial link between crustal extension and volcanism in that part of the Red Sea margin. As most important part of the lava pile is affected by the NE-SW $\left(\mathrm{N} 40^{\circ} \mathrm{E}\right)$ extension, Davison et al. (1994) argued that the rifting episode responsible for the opening of the Red Sea postdated the mantle plume activity in Yemen.

From the analysis of faulting-slip data sets and dykes in western Yemen, Huchon et al. (1991) recognized an early phase of E-W extension (30-26 Ma) which was associated with the main period of emplacement of the volcanic traps. They also have shown that the upper most part of Yemen volcanics was emplaced under a N-S extension until $18 \mathrm{Ma}$. Finally, Yemen was affected by NE-SW extension between 18 and $10 \mathrm{Ma}$, the former age being the age of the latest tilted volcanic flows and the later corresponding to Late Miocene tabular basaltic flows overlying tilted blocks. This NE-SW extension is responsible for the major structures in the Yemen volcanics. Therefore, both Huchon et al. (1991) and Davison et al. (1994) recognized that the $\mathrm{N} 40^{\circ} \mathrm{E}$ extension during the opening of the Red Sea was the major structuring event affecting the Yemeni crust. This extension is marked in the upper crust by the development of tilted blocks limited by normal faults and was probably contemporaneous with a rapid uplift of Yemen area (Menzies et al. 1992).

Menzies et al. (1997) suggested that the extension was largely post-volcanism because the volcanic stratigraphy is devoid of major faults. They propose that the extension occurred in the Late Oligocene-Early Miocene (after $26 \mathrm{Ma}$ ) with contemporaneous plutonic hypabyssal rocks while the initiation of magmatism occurred at $31 \mathrm{Ma}$. Geoffroy et al. (1998) further demonstrated that the Miocene alkali granites of Yemen, dated at 21 Ma (Capaldi et al. 1987; Huchon et al., 1991) are contemporaneous with the major Miocene extension post-dating the basaltic lava pile. Therefore, most of the previous work show that the main phase of extension related to rifting postdated the main mantle plume activity in Yemen. 


\section{Analysis of paleostresses}

Paleostress fields in Yemen were first analyzed by Huchon et al. (1991), who described successive phases of extension. Their work was limited to former North Yemen and was extended to former South Yemen by Huchon and Khanbari (2003). Paleostress analysis has also been performed further east in Dhofar (Sultanate of Oman) (Lepvrier et al. 2002; Fournier et al. 2004; Bellhasen et al. 2006) and in Socotra island (Fournier et al. 2007). Here we present the results of field studies in the volcanic part of Yemen, in three areas: the Dhala graben and the Taizz area in the south (Aden margin) and the Al-Mahwit area in the north (Red Sea margin). Our field data consist in measurements of faults, including slickenside lineations, and dikes. Most of these measurements were performed within the Tertiary volcanics. However, some outcrops in Jurassic limestones and Cretaceous sediments were also studied. Data analysis has been conducted using various methods (Angelier, 1984), including stress tensor computation by direct inversion of data (Angelier, 1990) for each sufficiently documented site.

Dhala area (Fig. 3)

The Dhala area is located in the southern part of Yemen, between longitudes $44^{\circ} 30^{\prime} \mathrm{E}$ and $45^{\circ} 30^{\prime} \mathrm{E}$, and latitudes $13^{\circ} \mathrm{N}$ and $14^{\circ} \mathrm{N}$ (Fig. 3). In the east of the Dhala area, the dominant trend of basement structures is NE-SW. The western part of the basement is characterized by NW-trending faults that bound the Dhala graben (Beydoun 1996, Thoué 1993). These faults separate Jurassic and Cretaceous blocks tilted towards the southwest. The analysis of these NW-trending faults (Fig. 3) indicates ENE-WSW $\left(\sim \mathrm{N} 70^{\circ} \mathrm{E}\right)$ extension (sites DH-1b, DH-2a, DH-5), NNE-SSW (N20 ${ }^{\circ}$ ) extension (site DH-2b) and NE-SW (N40 E) extension (site DH-6). Some NW faults have an oblique slip corresponding to a N-S direction of extension (site DH-1a and DH-2c). In the site DH-3, the faults that have NW-SE trend, correspond to NNE-SSW $\left(\sim \mathrm{N} 35^{\circ} \mathrm{E}\right)$ extension. The faults analysis in site DH-4 shows that the NW-SE and NE-SW faults indicate a direction of extension NNW-SSE. Three phases of extension have thus been recognized in this 
area: $\mathrm{ENE}\left(\mathrm{N} 70^{\circ} \mathrm{E}\right), \mathrm{NE}\left(\mathrm{N} 40^{\circ} \mathrm{E}\right)$ and the last one varies from NNE to NNW. The faults of sites DH-4, DH-3, DH-2 and DH-6 affect the Tertiary volcanics, while the faults of sites DH-1 and DH-5 affect the Cretaceous sandstones.

Taiz area (Fig. 4)

TAIZ area is located in the southern part of Yemen (Fig. 4), between longitudes $43^{\circ} 30^{\prime} \mathrm{E}$ and $44^{\circ} 30^{\prime} \mathrm{E}$, and latitudes $13^{\circ} \mathrm{N}$ and $14^{\circ} \mathrm{N}$. This area is characterized mainly by Tertiary volcanics, granitic intrusions and some outcrops of Cretaceous sandstones and Jurassic limestones overlying basement, which occurs mainly in the south-east part of the area. The analysis of faults shows that the direction of extension is chiefly N-S (sites TAIZ-1a, TAIZ-3, TAIZ-6a, TAIZ-7a). This extension corresponds to the faults trending E-W, ENE and WNW. Some faults oriented ENE originated from an extension oriented NNW (sites TAIZ-1b, TAIZ-2). At sites TAIZ-6b and TAIZ-5, the dip-slip slickensides of the faults shows NE extension, while some faults trending NW in the site TAIZ-6a have an oblique slip corresponding to a direction of extension N-S. The N-S phase of extension is thus younger than the NE one. In the northern part of this area, the dip-slip slickensides on conjugate faults trending N-S shows that the direction of extension is EW (site TAIZ-4, TAIZ-7b). Most of the phases of extension are recorded in the Tertiary volcanics except the site TAIZ-7a where the extension affected the cretaceous sandstones. Taiz area was thus affected by three Tertiary extensions: E-W extension, NE extension and N-S to NNW extension.

\section{Al-Mahwit area (Fig. 5)}

Al-Mahwit area is located in the northwestern part of Yemen. The simplified geological map of Al-Mahwit area (Fig. 5) shows that tertiary volcanics and granitic intrusions outcrop mainly in the area. The Jurassic limestones and the Cretaceous sandstones overlie the basement, which occurs in the north. The Quaternary sediments cover the coastal area (west of the study area) and some of outcrops of Jurassic limestone and Cretaceous 
sandstone occur in the coastal area (Tihama plain). Quaternary volcanics outcrop in the eastern part of the area.

Most of normal faults are dominantly oriented NW-SE. The granites which intruded flood basalts, are bounded by long, NW-trending normal faults at the NE and SW borders of the granites and by shorter, NE to ENE-trending faults on their northern and southern edges. Tilted blocks of Cretaceous sandstones and Tertiary volcanics dip towards the granites (Khanbari 2008). Dykes intrude theses blocks and the density of the tilted dykes increases towards the granites (Davison et al. 1994; Geoffroy et al. 1998). Geoffroy et al. (1998) proposed that the granites strongly control the geometry of tilted blocks.

The results of stress inversion from faults indicate that NW-SE conjugated normal faults are associated with the NE extension (sites MAHW-11, MAHW-10, MAHW-9, MAHW-16), while the NE-SW conjugated faults at site MAHW-25 is related to NWextension. At sites MAHW-19 and MAHW-17, the NE extension results almost from faults trending NW-SE. The oblique slip of some N-S to NNE-SSW trending faults at site MAHW-9 is associated with NW extension. At site MAHW-14, the NE-SW to N-S oriented faults are corresponding a WNW extension, while at site MAHW-22, the dip slip of NW faults and oblique slip of NNE to N-S and NNW faults indicate to NE extension.

Most of the observed faults affect the Tertiary volcanics (sites MAHW-17, MAHW-19, MAHW-20, MAHW-16 and MAHW-22), but some of them are also observed in Cretaceous sandstones (MAHW-11) and in Jurassic limestones (site MAHW10). Most of the dykes in the study area are oriented NE-SE and NW-SE. Many of them were tilted with the crustal blocks. The dominantly SW and SE grouping of poles of dykes reveals NE and NW extension (Fig. 6). Some dykes have N-S trending and the grouping of their poles maybe related to the E-W extension that was recognized in Yemen by Huchon et al. (1991) and Mohr (1991). The NW-SE trending dykes are mechanically compatible with the extension responsible for the tilting, while the NE-SW dykes are perpendicular and may represent a later phase of magma injection. In summary, the Al-Mahwit area is affected by three extensional stress regimes: NE extension, NW extension and WNW to E-W extension. 


\section{Relative chronology of faulting events}

Our field survey and the analysis of the data indicate that the volcanic margin of Yemen is affected by three main Oligo-Miocene extensions: E-W, NE and NNW. Most of the normal faults have been observed in Tertiary volcanics, which confirms the Oligomiocene age of faulting. The relative chronology of these phases is based on our faults analysis and the previous works in the area.

Huchon et al. (1991) recognized in the west of Yemen an early (30-26? Ma) E-W extension, which was associated with the main period of emplacement of the volcanics traps. The absence of this extension in the eastern part of Yemen (Huchon and Khanbari 2003) confirms its relation with the emplacement of the Tertiary volcanics as the result of the increasing influence of Afar plume towards the west. The tilting of N-S trending dykes in Al-Mahwit area is another argument in favor of the early character of the E-W extension.

The NE extension had been identified by Huchon et al. (1991) and Davison et al. (1994) as the major structuring event in western part of Yemen. This extension affected the lava pile, thus it is post dated the main mantle plume activity in Yemen. NNW to N-S extension was also observed in the western part of Yemen by Huchon et al. (1991).

The NE and NNW extensions are also recorded in the eastern part of Yemen, along the Gulf of Aden, as Oligo-Miocene syn-rift extensions (Thoué 1994; Huchon and Khanbari 2003). Thoué et al. (1994) proposed that the NNW extension predates the NE extension, while Huchon et al. (1991) proposed that NE extension predates the NNW extension. However, Thoué's observations were made in Jurassic limestones, and there is a possibility that the early NNW extension they observed is actually a Late Jurassic to Cretaceous one.

In our structural analysis, some oblique slip slickensides of NW trending faults shows that the NE extension is older than NNW one (site TAIZ-7c in Taiz area and site DH-2c in Dhala area), where the oblique slickensides on NW-SE trending faults corresponds to NNW extension. This indicates that the faults have been reactivated under a younger NNW extension. This observation is consistent with the chronology established further east by Huchon and Khanbari (2003). 


\section{Discussion and conclusion}

Our analysis suggests that there is a strong link between magmatism and extension and that the evolution of the volcanic margin is closely related to Afar plume, which is responsible for the generation of basic and acidic traps. The presence of syn-volcanic structures indicates that some extension did occur during the emplacement of the early volcanics around $30 \mathrm{Ma}$. However, most crustal extension postdated this early magmatic phase.

We propose two main stages of evolution of the Yemen volcanic margin in relation with the hotspot and plate movement (Table 1). The first stage is an E-W syn-magmatic extension, coeval with the emplacement of most volcanic pile. The presence of this extension in the western part of Yemen and its absence in the southern-eastern Yemen (Huchon and Khanbari 2003) resulted from its position near the influence of the Afar plume. The second stage of evolution of the volcanic margin is a post-magmatic extension, which associated with NE-SW and NNW-SSE extensions. Our structural analysis indicates that the NE extension predates the NNW extension. We propose that the major NE extension is related to the rifting of the Red Sea and the Gulf of Aden (starting also at about $30 \mathrm{Ma}$ ) and to the movement to the Arabian plate. The NE extension is perpendicular to the Red Sea rifting and was marked by NW-SE trending faults; it is also parallel to the Arabian plate movement towards the NE. On the other hand, the NNW extension which is perpendicular to the general trend of the Gulf of Aden $\left(\mathrm{N} 70^{\circ} \mathrm{E}\right)$, is related to the opening and the propagation of the Sheba ridge toward the west.

The volcanic margin of Yemen is therefore complex and presents a combination of both active and passive processes. At $30 \mathrm{Ma}$, the volcanic margin was part of an active rift where the E-W extension was driven by the Afar plume. The post-volcanic NE and NNW extensions are consistent with a passive model of rifting, where the extension results from far-field forces related to the plate motion as well as the local effect of the westward propagation of the Sheba ridge. 
Acknowledgements The French Foreign Affairs Ministry and CNRS have funded the fieldwork in Yemen, with the logistical support of the Sana'a University. We thank JeanMichel Gaulier and Laurent Geoffroy for their contribution to the fieldwork. We also thank F. Roure for giving us the opportunity to publish these data and an anonymous reviewer for his constructive remarks on a previous version of this paper.

\section{References}

Angelier J (1984) Tectonic analysis of fault slip data sets. J. Geophys. Res. 89 (B8), 5835-5848.

Angelier J (1990) Inversion of field data in fault tectonics to obtain the regional stressIII. A new rapid direct inversion method by analytical means. Geophys. J. Int. 103, $363-376$.

Audin L (1999) Pénétration de la dorsale d'Aden dans la dépression Afar entre 20 et 4 Ma. PhD thesis, Paris 7 University, France, 278 pp.

Baker J, Snee L, Menzies M (1996) A brief Oligocene period of flood volcanism in Yemen: implications for duration and rate of continental flood volcanism at the Afro-Arabian triple junction. Earth Planet. Sci. Lett. 138, 39-55.

Bellahsen N, Fournier M, d'Acremont E, Leroy S, Daniel JM (2006), Fault reactivation and rift localization: The northeastern Gulf of Aden margin. Tectonics, 25, TC1007, doi : 10.1029/2004TC001747.

Beydoun ZR (1964) The stratigraphy and structure of the eastern Aden protectorate. Overseas Geol. and Mineral Resources, Bull. Supp. 5, HMSO, London, pp. 107.

Beydoun ZR (1970) Southern Arabia and northern Somalia: comparative geology. Phil. Trans. Roy. Soc. London A.267, 267-292.

Beydoun Z, As-Sasuri M, Baraba R (1996) Sedimentary basins of the Republic of Yemen: their structural evolution and geological characteristics. Rev. Inst. Fr. Pet. $51(6)$.

Bosence D W (1997) Mesozoic rift basins of Yemen. Mar. Petrol. Geol. 14 (6), 611-616.

Bosworth W, Huchon P, McClay K (2005) The Red Sea and Gulf of Aden basins. Journ. Afr. Earth Sc. 43, 334-378. 
Bott WF, Smith BA, Oakes G, Sikander AH, Ibrahim AI (1992) The tectonic framework and regional hydrocarbon prospectivity of the Gulf of Aden. Journ. Petrol. Geol. 15, 211-243.

Brannan J, Sahota G, Gerdes KD, Berry JAL (1999) Geological Evolution of the Central Marib-Shabwa Basin, Yemen. GeoArabia 4 (1), Gulf PetroLink, Bahrain.

Capaldi G, Chiesa S, Manetti P, Orsi G, Poli G (1987) Tertiary anorogenic granites of the western border of the Yemen Plateau. Lithos 20, 433-444.

Chazot G, Bertrand H (1995) Genesis of silicic magmas during Tertiary continental rifting in Yemen. Lithos 36, 69-84.

Chazot G, Menzies MA, Baker J (1998) Pre-, syn- and post-rift volcanism on the southwestern margin of the Arabian plate. In Purser, B.H. and Bosence, D.W.J., Eds, Sedimentation and tectonics of rift basins: Red Sea - Gulf of Aden. Chapman \& Hall, London, 50-56.

Chiesa S, La Volpe L, Lirer L, Orsi G (1983) Geological and structural outline of Yemen Plateau, Yemen Arab Republic. N. Jb. Geol. Paläont. Mh. 11, 641-656.

Chiesa S, Civetta L, De Fino M, La Volpe L, Orsi G (1989) The Yemen trap series: genesis and evolution of a continental flood basalt province. J. Volcanol. Geotherm. Res. 36, 337-350.

Civetta L, Lavolpe L, Lirer L (1978) K-Ar ages of the Yemen plateau. J. Volcanol. Geotherm. Res. 4, 307-314.

Cochran JR (1981) The Gulf of Aden: Structure and Evolution of a Young Ocean Basin and Continental Margin. J. Geophys. Res. 86 (B1), 263-287.

Cochran JR (1983) A model for development of the Red Sea. Bull. Amer. Ass. Petrol. Geol. 67, 41-69.

Courtillot V, Galdéano A, Le Mouel JL (1980) Propagation of an accreting plate boundary: a discussion of new aeromagnetic data in the Gulf of Tadjurah and Southern Afar. Earth Planet. Sci. Lett. 47, 144-160.

Dauteuil O, Huchon P, Quemeneur F, Souriot T (2001) Propagation of an oblique spreading center: the western Gulf of Aden. Tectonophysics 332, 423-442.

Davison I, Al-Kadasi M, Al-Khirbash S, Al-Subbary AK, Baker J, Blakey S, Bosence D, Dart C, Heaton R, McClay K, Menzies M, Nicols G, Owen L, Yelland A (1994) 
Geological evolution of the southeastern Red Sea Rift margin, Republic of Yemen. Bull. Geol. Soc. Am. 106, 1474-1493.

d'Acremont E, Leroy S, Maia M, Gente P, Autin J (2010) Volcanism, jump and propagation on the Sheba ridge, eastern Gulf of Aden: segmentation evolution and implications for oceanic accretion processes. Geophys. J. Int.,180, 535-551, doi: 10.1111/j.1365-246X.2009.04448.x

Ellis AC, Kerr HM, Cornwell CP, Williams DO (1996) A tectono-stratigraphic framework for Yemen and its implications for hydrocarbon potential. Petroleum Geoscience 2, 29-24.

Ehrhardt A, Hübscher C, Gajewski D (2005) Conrad Deep, Northern Red Sea: Development of an early stage ocean deep within the axial depression. Tectonophysics, 411, 19-40.

Fantozzi PL (1996) Transition from continental to oceanic rifting in the Gulf of Aden: structural evidence from field mapping in Somalia and Yemen. Tectonophysics, 259, 285-311.

Fournier M, Bellahsen N, Fabbri O, Gunnell Y (2004) Oblique rifting and segmentation of the NE Gulf of Aden passive margin. Geochemistry Geophysics Geosystems, 5, Q11005, doi:10.1029/2004GC000731.

Fournier M, Huchon P, Khanbari K, Leroy S (2007) Segmentation and along-strike asymmetry of the passive margin in Socotra, eastern Gulf of Aden: are they controlled by detachment faults? G-cubed, 8(3), doi:10.1029/2006GC001526.

Fournier M, Chamot-Rooke N, Petit C, Huchon P, Al-Kathiri A, Audin L, Beslier MO, d'Acremont E, Fabbri O, Fleury JM, Khanbari K, Lepvrier C, Leroy S, Maillot B, Merkouriev S (2010) Arabia-Somalia plate kinematics, evolution of the AdenOwen-Carlsberg triple junction, and opening of the Gulf of Aden, J. Geophys. Res., 115, B04102, doi:10.1029/2008JB006257.

Gaulier JM, Huchon P (1991) Tectonic evolution of Afar triple junction. Bull. Soc. géol. France. 126, 451-464.

Geoffroy L, Huchon P, Khanbari K (1998) Did Yemeni Tertiary granites intrude neck zones of a stretched continental upper crust? Terra Nova 10, 169-200. 
Geukens F (1960) Contribution à la géologie du Yémen. Mém. Inst. Géol. Univ. Louvain. 21, 117-180.

Greenwood JEGW, Beackley D (1967) Geology of the Arabian peninsula, Aden Protectorate. U.S.G.S Professional Paper. 560-C, 1-95.

Haitham FM, Nani ASO (1990) The Gulf of Aden Rift : Hydrocarbon Potential of the Arabian Sector. Journ. Petrol. Geol. 13 (2), 211-220.

Hoffmann C, Courtillot V, Féraud G, Rochette P, Yirgu E, Kefeto E, Pik R (1997) Timing of the Ethiopian flood basalt event and implications for plume birth and global change. Nature 389, 838-841.

Huchon P, Jestin F, Cantagrel JM, Gaulier JM, Al-Khirbash S, Gafaneh A (1991) Extensional deformations in Yemen since Oligocene and the Afar triple junction. Annales Tectonicae 5 (2), 141-163.

Huchon P, Khanbari K (2003) Rotation of the syn-rift stress field of the northern Gulf of Aden margin, Yemen. Tectonophysics 364, 147-166.

Hughes GW, Varol O, Beydoun ZR (1991) Evidence for middle Oligocene rifting of the Gulf of Aden and for late Oligocene rifting of the southern Red Sea. Mar. Petrol. Geol., 8, 354-358.

Izzeldin AY (1987) Seismic, gravity and magnetic surveys in the central part of the Red Sea: their interpretation and implications for the structure and evolution of the Red Sea, Tectonophysics, 143, 269-306.

Khanbari K (2008) Study of Structures and Tectonic Evolution of Yemen Tertiary Granites, by Using Remote Sensing Technique. J. of Remote Sensing issued by GORS, v. 21, P 63-72.

Laughton AS, Whitmarsh RB, Jones MT (1970) The evolution of the gulf of Aden, Phil. Trans. Roy. Soc., A267, 227-266.

Lepvrier C, Fournier M, Bérard T, Roger J (2002) Cenozoic extension in coastal Dhofar (southern Oman): implications on the oblique rifting of the Gulf of Aden. Tectonophysics, 357, 279-293.

Le Pichon X, Francheteau J (1978) A plate tectonic analysis of the Red Sea-Gulf of Aden area. Tectonophysics 46, 369-406. 
Le Pichon X, Gaulier JM (1988) The rotation of Arabia and the Levant fault system. Tectonophysics 153, 271-274.

Leroy S, Gente P, Fournier M, d'Acremont E, Bellahsen N, Beslier MO, Patriat P, Maia M, Blais A, Perrot J, Al-Kathiri A, Merkouriev S, Ruellan PY, Fleury JM, Lepvrier C, Huchon P (2004) From rifting to spreading in the eastern Gulf of Aden: a geophysical survey of a young oceanic basin from margin to margin. Terra Nova, 16, 185-192.

Manighetti I, Tapponnier P, Courtillot V, Gruszow S, Gillot PY (1997) Propagation of rifting along the Arabia-Somalia plate boundary: the gulfs of Aden and Tadjoura. Journ. Geophys. Res. 102, 2681-2710.

Manighetti I, Tapponnier P, Gillot PY, Jacques E, Courtillot V, Armijo R, Ruegg JC, King G (1998) Propagation of rifting along the Arabia-Somalia plate boundary: into Afar. Journ. Geophys. Res. 103, 4947-4974.

Menzies M, Baker J, Bosence D, Dart C, Davidson I, Hurford A, Al-Kadasi M, McClay K, Nichols G, Al-Subbary A, Yelland A (1992) The timing of magmatism, uplift and crustal extension : preliminary obervations from Yemen. In : "Magmatism and the causes of continental Beak-Up", B.C. Storey, T. Alabaster and R.J. Pankhurst, Eds. Spec. Publ. Geol. Soc. London 68, 293-304.

Menzies M, Baker J, Chazot G, Al-Kadasi M (1997) Evolution of the Red sea volcanic margin, western Yemen. In Large igneous provinces: continental, oceanic and planetary flood volcanism, Geophysical Monograph 100, American Geophysical Union, 29-43.

Mohr P (1991) Structure of Yemen Miocene dike swarms, and emplacement of coeval granite plutons. Tectonophysics 198, 203-221.

Redfern P, Jones JA (1995) The interior rifts of the Yemen. Analysis of basin structure and stratigraphy in a regional plate tectonic context. Basin Research 7, 337-356.

Riisager P, Knight KB, Baker JA, Ukstins Peate I, Al-Kadasi M, Al-Subbary A, Renne PR (2005) Paleomagnetism and 40Ar / 39Ar Geochronology of Yemeni Oligocene volcanics: Implications for timing and duration of Afro-Arabian traps and geometry of the Oligocene paleomagnetic field. Eath Planet. Sc. Lett., 237, 647-672. 
Sahota G (1990) Geophysical investigations of the Gulf of Aden Continental Margins : Geodynamic implications for the Development of the Afro-Arabian Rift System. Ph.D. Thesis, University College, Swansea, UK.

Schüppel D, Wienholz R (1990) The development of Tertiary in the Habban-Al Mukalla area, PDR Yemen. Z. geol. Wiss., Berlin 6, 523-528.

Tard F, Masse P, Walgenwitz F, Gruneisen P (1991) The volcanic passive margin in the vicinity of Aden, Yemen. Bull. Centr. Rech. Explor.-Prod. Elf-Aquitaine 15(1), 1-9.

Thoué F, Vidal G, Gratier JP (1994) Quantification par imagerie 3D d'un champ de déplacements sur la marge sud du Yémen: implications sur l'ouverture du golfe d'Aden. C.R. Acad. Sci. Paris 319, série II, 825-832.

Watchorn F, Nichols GJ, Bosence DWJ (1998) Rift-related sedimentation and stratigraphy, southern Yemen (Gulf of Aden). In "Sedimentation and tectonics in the Rift Basins Red Sea-Gulf of Aden". B. Purser and D. Bosence, Eds. Chapman et Hall, London. 165-189.

Whitehouse MJ, Windley BF, Stoeser DB, Al-Khirbash S, Ba-Bttat MAO, Haider A, (2001) Precambrian basement character of Yemen and correlations with Saudi Arabia and Somalia. Precambrian Res. 105, 357 - 369.

Ziegler MA (2001) Late Permian to Holocene paleofacies evolution of the Arabian plate and its hydrocarbon occurrences. GeoArabia 6 (3), 445-503.

Zumbo V, Féraud G, Bertrand H, Chazot G (1995) ${ }^{40} \mathrm{Ar}-{ }^{39} \mathrm{Ar}$ geochronology of the Tertiary magmatic activity in south-western Yemen during the early Red Sea-Gulf of Aden rifting. J. Volcanol. Geotherm. Res. 65, 265-279. 


\section{Figure Captions:}

Fig.1: Geodynamic context of the studied area. Arrows show the directions of relative plate motions.

Fig.2: Simplified geological and structural map of Yemen and location of the three study areas.

Fig.3: Geological and structural map of Dhala area (location on fig.2) and stereographic plots of faults (lower hemisphere). Black arrows: direction of extensional stress. 3-, 4and 5-branches stars are the minimum, intermediate and maximum principal stress axes, respectively.

Fig.4: Geological and structural map of Taiz area (location on fig.2) and stereographic plots of faults. Black arrows: direction of extensional stress. 3-, 4- and 5- branches stars are the minimum, intermediate and maximum principal stress axes, respectively.

Fig.5: Geological and structural map of Al-Mahwit area (location on fig.2) and stereographic plots of faults. Black arrows: direction of extensional stress. 3-, 4- and 5branches stars are the minimum, intermediate and maximum principal stress axes, respectively.

Fig.6: Poles of dykes (squares) in Al-Mahwit area. Lower-hemisphere Schmidt projection. Dashed: mean bedding of sedimentary and volcanic bed. Black arrows: inferred direction of extension. Set 1 occurred before tilting, set $2 \mathrm{a}$ is syn-tilting and set $2 \mathrm{~b}$ may be younger (see text). 


\begin{tabular}{|c|c|c|c|c|c|c|}
\hline \multirow{3}{*}{ AGE } & \multirow{3}{*}{ EVENTS } & \multicolumn{4}{|c|}{ Volcanic margin } & Non-volc. \\
\hline & & \multicolumn{3}{|c|}{ Red Sea } & \multicolumn{2}{|c|}{ Gulf of Aden } \\
\hline & & Djibouti & Al-Mahwit & Taiz & Dhala & East Yemen \\
\hline $3 \mathrm{Ma}$ & $\begin{array}{l}\text { Tadjoura } \\
\text { spreading }\end{array}$ & & & & & \\
\hline $5 \mathrm{Ma}$ & Red Sea spr. & & & & & \\
\hline $9 \mathrm{Ma}$ & $\begin{array}{l}\text { Western Gulf } \\
\text { of Aden spr. }\end{array}$ & & & & & \\
\hline $20 \mathrm{Ma}$ & $\begin{array}{l}\text { Eastern Gulf } \\
\text { of Aden spr. }\end{array}$ & & & & & \\
\hline $21 \mathrm{Ma}$ & Red Sea uplift & & & & & \\
\hline $30 \mathrm{Ma}$ & Afar trapps & & & & & \\
\hline
\end{tabular}

Table 1. Summary of reconstructed paleostresses with their inferred age in relation to the main geodynamics events. Directions for Djibouti and Eastern Yemen are from Gaulier and Huchon (1991) and Huchon and Khanbari (2003), respectively. The dashed line shows the propagation of the oceanic ridge in the Gulf of Aden. 


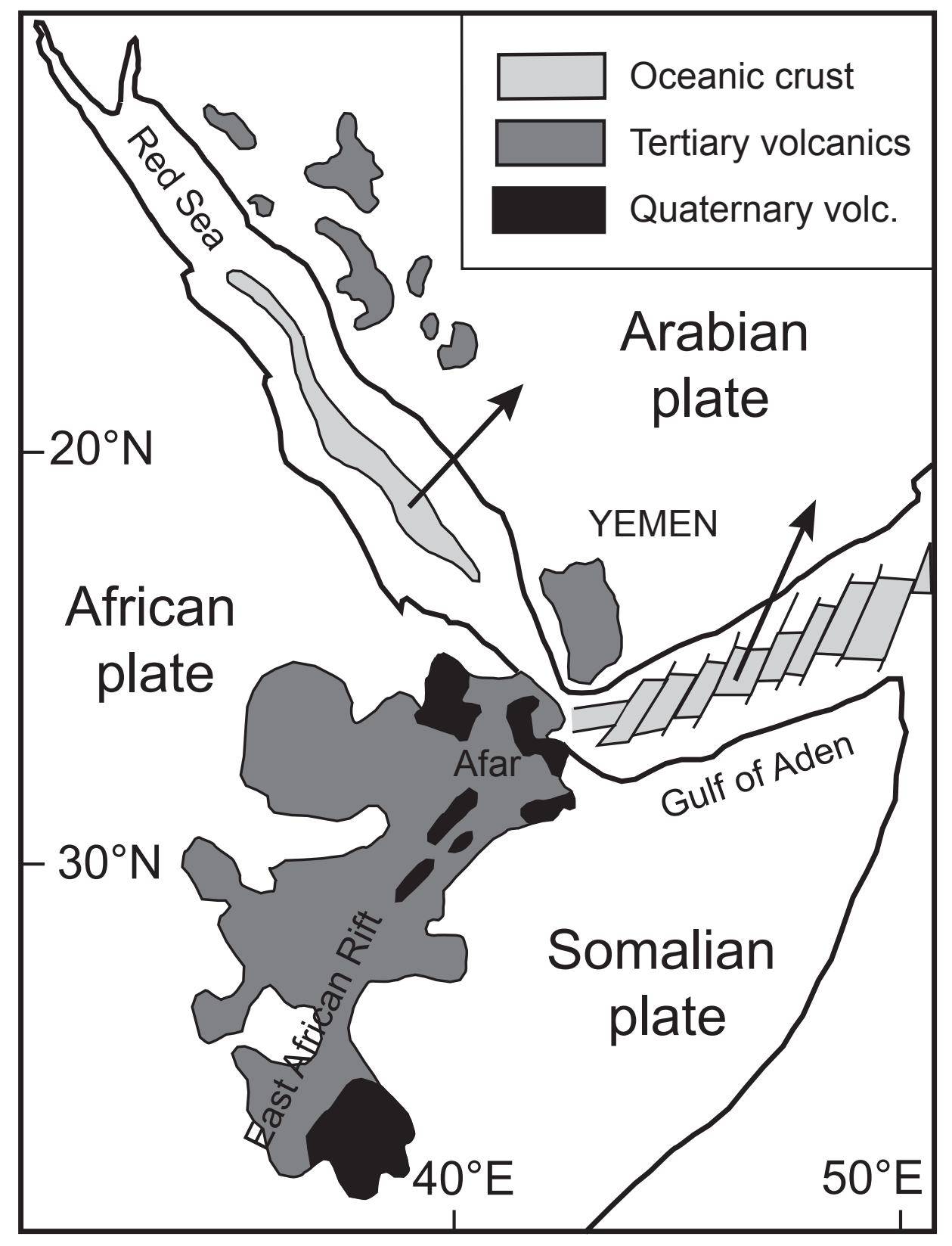

Figure 1 


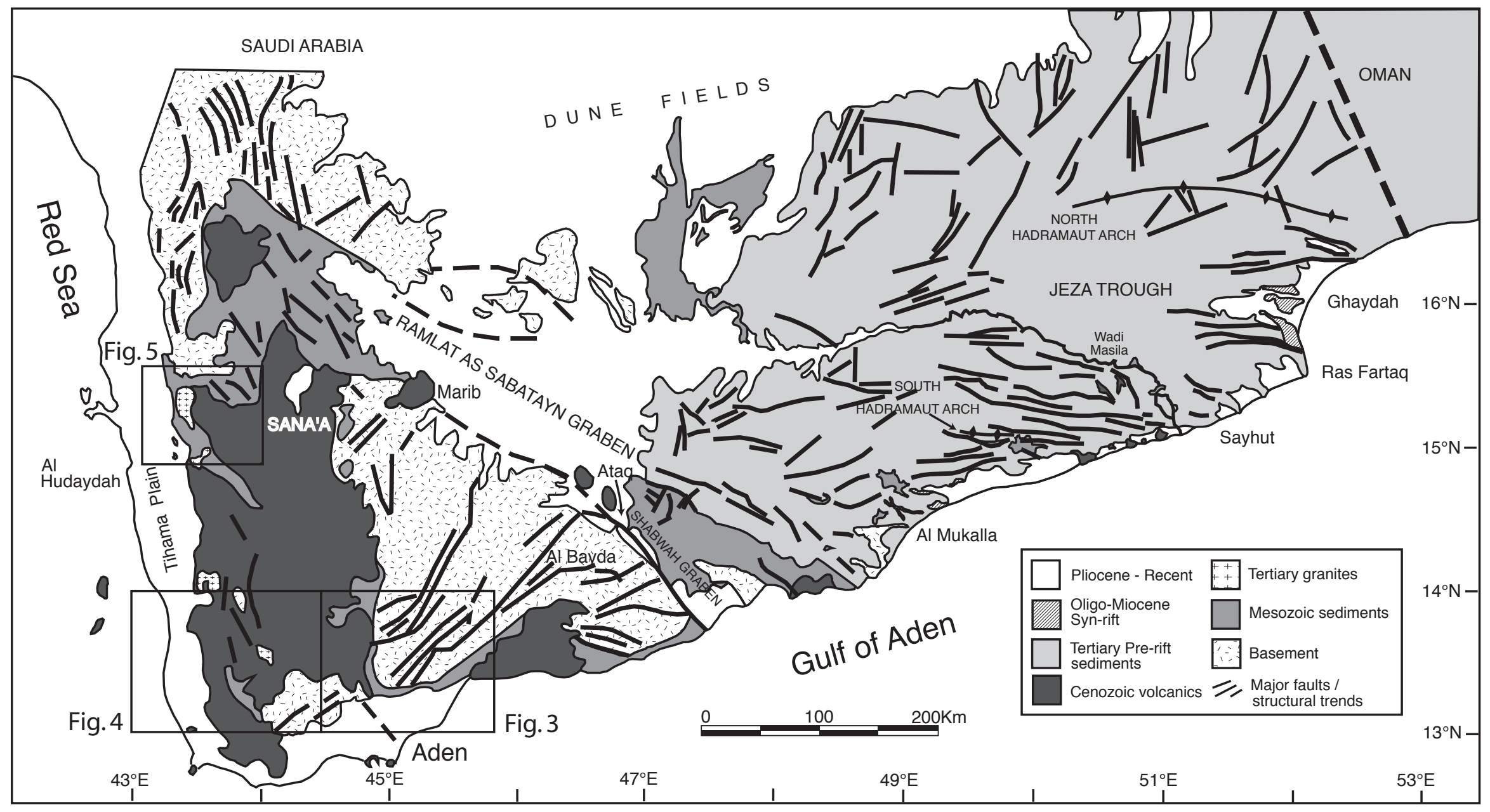

Figure 2 


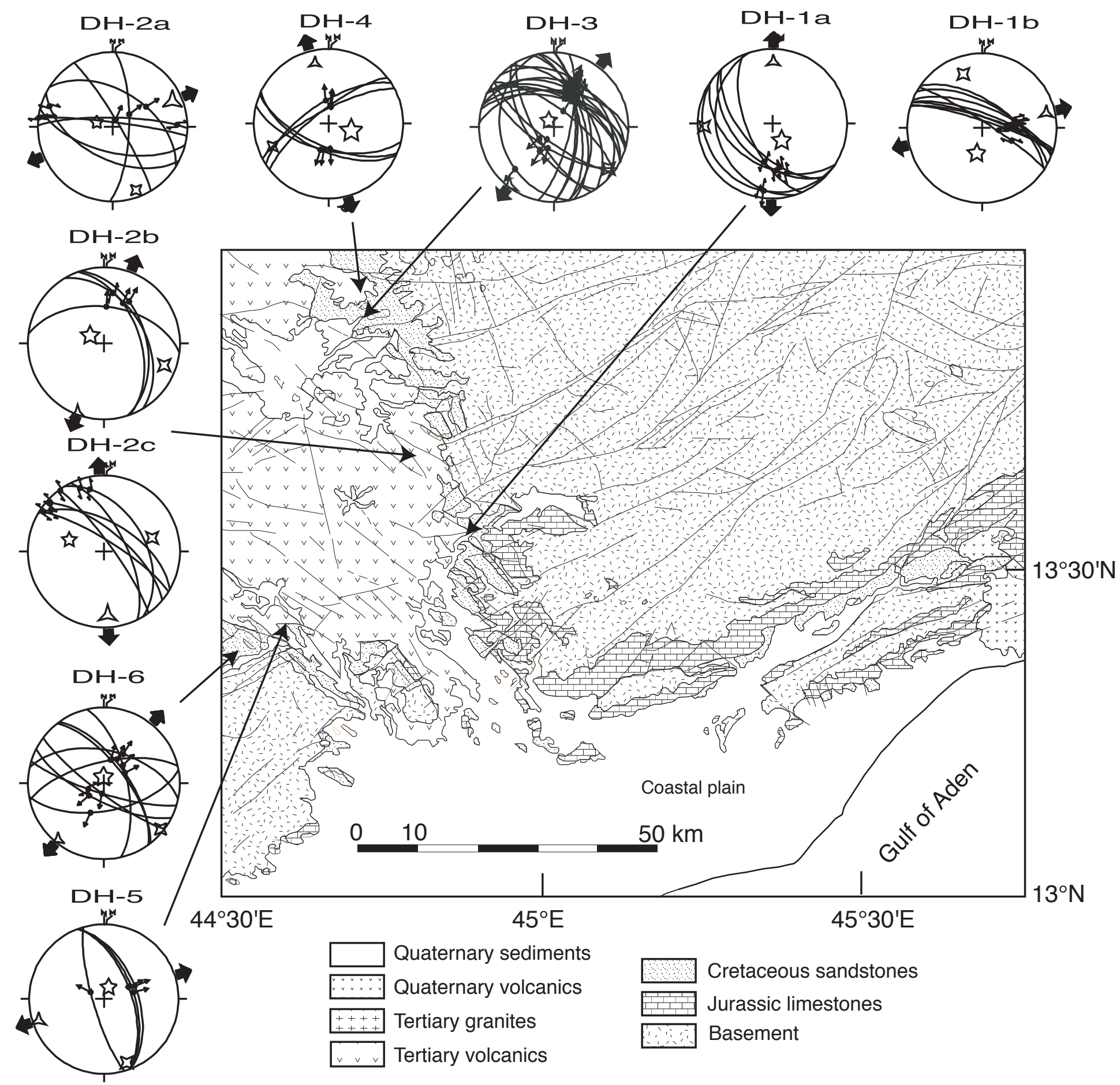

Figure 3 


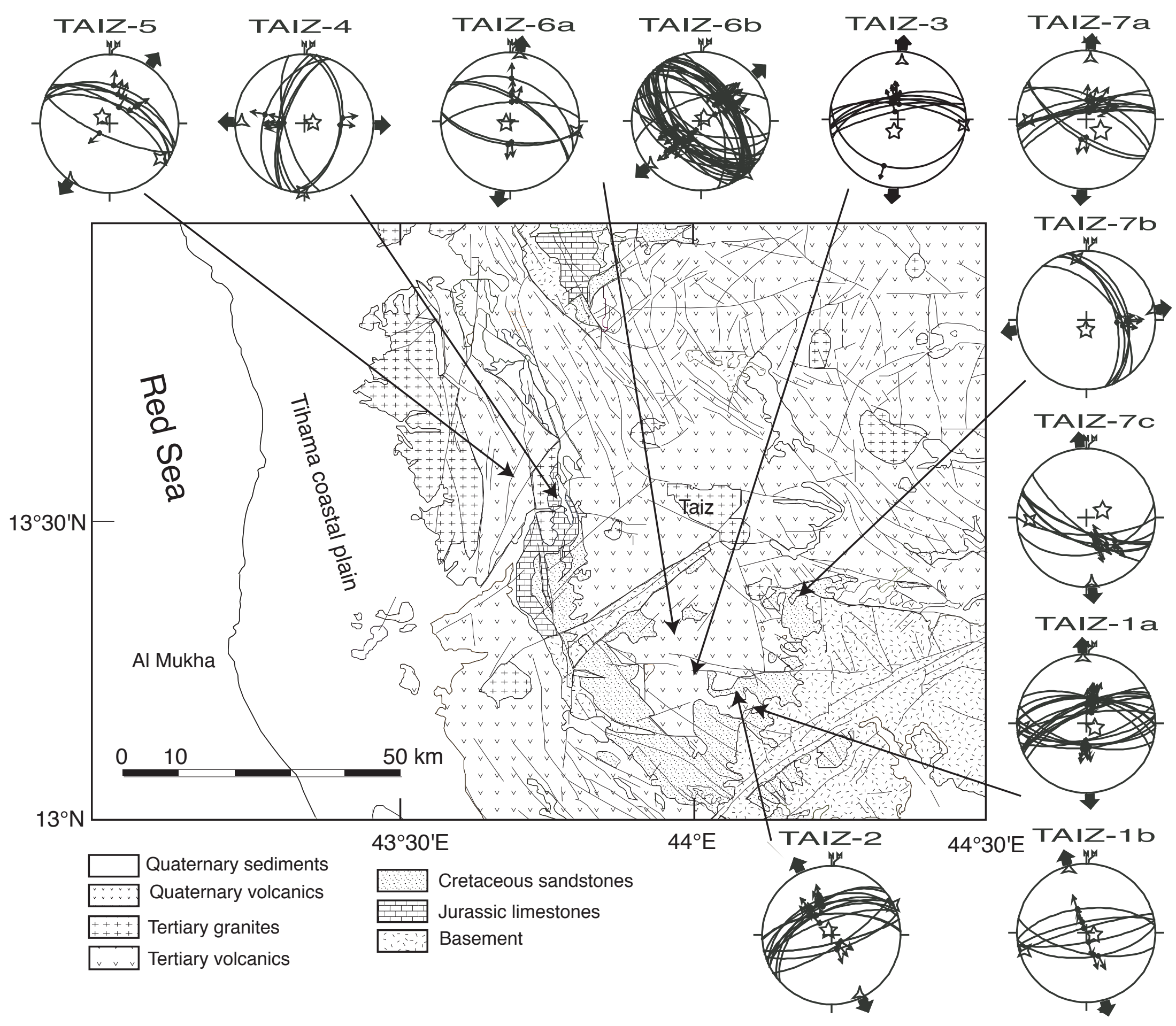




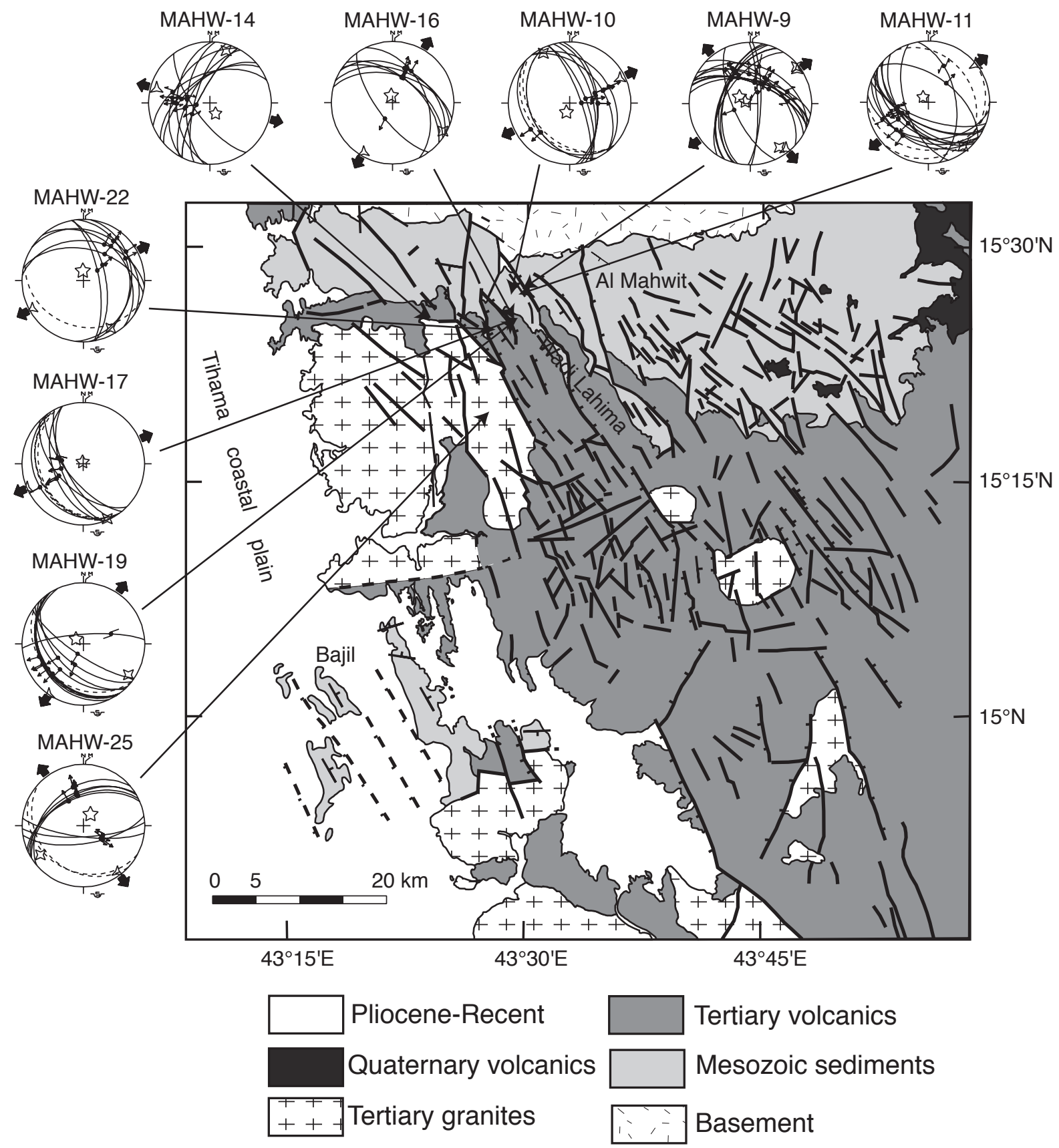




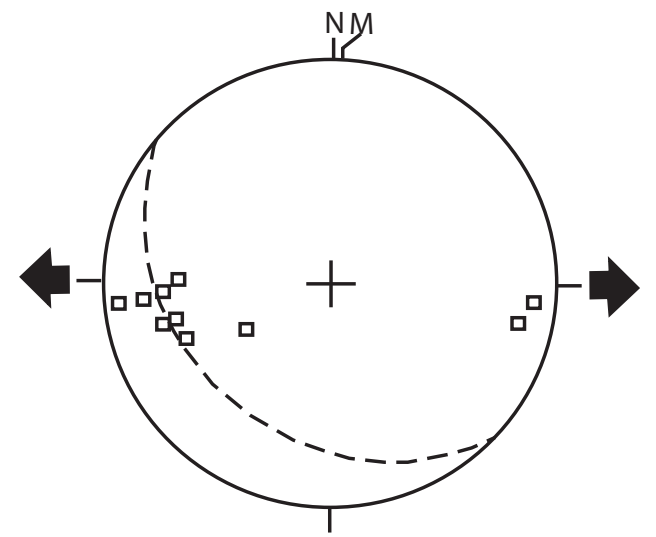

(1)

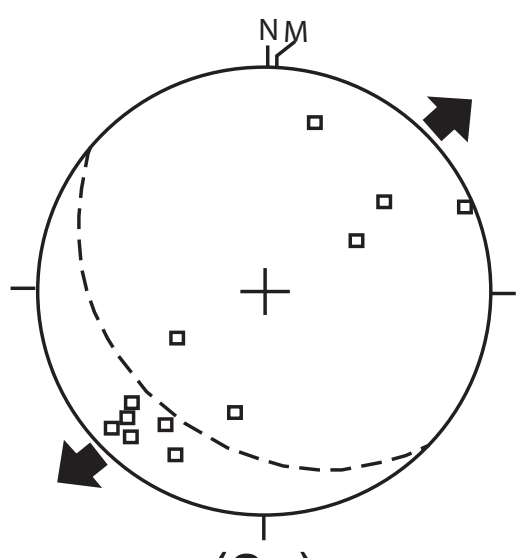

(2a)

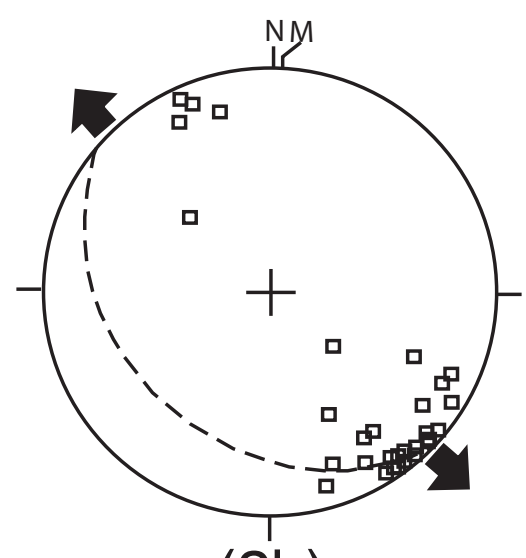

(2b)

Figure 6 